\title{
Basic helix-loop-helix proteins E2A and HEB induce immature T-cell receptor rearrangements in nonlymphoid cells
}

Anton W. Langerak, Ingrid L. M. Wolvers-Tettero, Ellen J. van Gastel-Mol, Monique E. C. M. Oud, and Jacques J. M. van Dongen

T-cell receptor (TCR) gene rearrangements are mediated via $V(D) J$ recombination, which is strictly regulated during lymphoid differentiation, most probably through the action of specific transcription factors. Investigated was whether cotransfection of RAG1 and RAG2 genes in combination with lymphoid transcription factors can induce TCR gene rearrangements in nonlymphoid human cells. Transfection experiments showed that basic helix-loop-helix transcription factors E2A and HEB induce rearrangements in the TCRD locus (D $\delta 2-D \delta 3$ and V $\delta 2-D \delta 3$ )

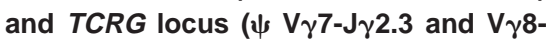
$\mathrm{J} \gamma 2$.3). Analysis of these rearrangements and their circular excision products re- vealed some peculiar characteristics. The V $\delta 2-D \delta 3$ rearrangements were formed by direct coupling without intermediate $D \delta 2$

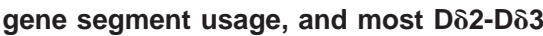
recombinations occurred via direct coupling of the respective upstream and downstream recombination signal sequences (RSSs) with deletion of the D $\delta 2$ and $D \delta 3$ coding sequences. Subsequently, the E2A/HEB-induced TCR gene recombination patterns were compared with those in early thymocytes and acute lymphoblastic leukemias of T- and B-lineage origin, and it was found that the TCR rearrangements in the transfectants were early (immature) and not necessarily $\mathrm{T}$ lineage specific. Apparently, some parts

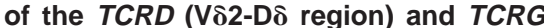
genes are accessible for recombination not only in T cells, but also in early B-cells and even in nonlymphoid cells if the appropriate transcription factors are present. The transfection system described here appeared to be useful for studying the accessibility of immunoglobulin and TCR genes for V(D)J recombination, but might also be applied to study the induction of RSS-mediated chromosome aberrations. (Blood. 2001;98: 2456-2465)

๑ 2001 by The American Society of Hematology

\section{Introduction}

Antigen recognition by lymphocytes is dependent upon successful rearrangement of immunoglobulin and T-cell receptor (TCR) genes from variable (V), diversity (D), and joining (J) gene segments through the process of $\mathrm{V}(\mathrm{D}) \mathrm{J}$ recombination. ${ }^{1}$ The rearrangement processes are mediated by the recombination-activating gene (RAG)-1 and RAG2 proteins, which specifically recognize the recombination signal sequences (RSSs) that flank the coding regions of the V, D, and J gene segments..$^{2-4}$ RSSs are consensus sequences consisting of a heptamer and nonamer separated by a 12-base pair (bp) or 23-bp spacer. Site-specific cleavage at the borders of RSSs and coding elements by the RAG proteins is followed by a process of rejoining of DNA ends in which the double-strand break-repair enzymes play a central role. Antigen receptor assembly is critically dependent upon expression of the lymphoid-specific RAG proteins; this is further illustrated by the fact that ectopic RAG expression results in site-specific recombination both in vitro and in vivo. ${ }^{2-4}$

The whole process of $\mathrm{V}(\mathrm{D}) \mathrm{J}$ recombination is ordered and tightly regulated during lymphoid differentiation. ${ }^{5}$ The hierarchical order is apparent at different levels. First, cells committed to the B-cell lineage undergo immunoglobulin rearrangements, whereas TCR genes rearrange in T-cell precursors. Nevertheless, so-called cross-lineage rearrangements might occasionally occur in precursor B and $\mathrm{T}$ cells; this phenomenon is particularly evident from

From the Department of Immunology, Erasmus University Rotterdam/University Hospital Rotterdam, The Netherlands.

Submitted March 7, 2001; accepted May 10, 2001.

Supported by grant EUR 95-1015 from the Dutch Cancer Society (Koningin Wilhelmina Fonds); and additional financial support (to A.W.L.) from the Haak Bastiaanse Kuneman Foundation. malignantly transformed lymphoid precursor cells, ie, B- and T-lineage acute lymphoblastic leukemias (ALLs). ${ }^{6,7}$ Furthermore, immunoglobulin $(\mathrm{Ig})$ heavy chain $(I G H)$ rearrangements are known to precede Ig kappa $(I G K)$ and Ig lambda light-chain recombination. ${ }^{8}$ Similarly, data from human T-ALL and sorted human thymocyte subpopulations indicate that TCR $\delta(T C R D)$ recombination occurs prior to TCR $\gamma(T C R G)$ and TCR $\beta$ (TCRB) rearrangement, whereas the TCR $\alpha$ (TCRA) locus is rearranged at a late stage only. ${ }^{9-11}$ The ordered process is also apparent from the finding that $\mathrm{D}_{\mathrm{H}^{-}} \mathrm{J}_{\mathrm{H}}$ or $\mathrm{D} \beta-\mathrm{J} \beta$ rearrangements generally precede the coupling of their respective $\mathrm{V}$ gene segments. ${ }^{12,13}$ Finally, regulation can occur even at the level of gene segment usage, as is apparent from murine thymic ontogeny where $\mathrm{V} \gamma$ and $\mathrm{V} \delta$ gene rearrangements occur in waves with different $\mathrm{V}$ segments being used in fetal and adult thymocytes. ${ }^{14,15}$

It has been suggested that the tight and hierarchical regulation of the rearrangement processes can be explained by differential chromatin accessibility to the $\mathrm{V}(\mathrm{D}) \mathrm{J}$ recombinase, ${ }^{16}$ which in turn is controlled by transcription factors binding to promoters and enhancers. E proteins are an important class of transcription factors in lymphoid differentiation. They consist of a helix-loop-helix (HLH) dimerization motif and a basic DNA binding domain that binds to conserved E-box motifs, as identified in immunoglobulin, $T C R B$, and CD4 enhancers. Members of the E-protein family
Reprints: Anton W. Langerak, Department of Immunology, Erasmus University Rotterdam/University Hospital Rotterdam, PO Box 1738, 3000 DR Rotterdam, The Netherlands; e-mail: langerak@immu.fgg.eur.nl.

The publication costs of this article were defrayed in part by page charge payment. Therefore, and solely to indicate this fact, this article is hereby marked "advertisement" in accordance with 18 U.S.C. section 1734.

(c) 2001 by The American Society of Hematology 
include E2-2, HEB, and the E12 and E47 splice variant products of the $E 2 A$ gene. ${ }^{17} \mathrm{E} 12$ and $\mathrm{E} 47$ are differentially expressed in a wide variety of tissues, but exist as homodimers only in B-lineage cells. ${ }^{18,19}$ In T cells, E-box binding complexes are heterodimers of $\mathrm{E} 2 \mathrm{~A}$ and HEB. E2A ${ }^{-1-}$ mice have a block in B-cell differentiation prior to the start of the immunoglobulin recombination process..$^{20,21}$ Induction of $\mathrm{D}_{\mathrm{H}^{-}} \mathrm{J}_{\mathrm{H}}$ and $I G K$ rearrangements upon ectopic E2A expression in a pre-T-cell line or even nonlymphoid human cells illustrates its involvement in regulation of $\mathrm{V}(\mathrm{D}) \mathrm{J}$ recombination. ${ }^{22,23} \mathrm{E}^{2} \mathrm{~A}^{-1-}$ mice also have a severe, though less complete, defect in T-cell differentiation at the double-negative stage. Interestingly, in $\mathrm{E}^{2} \mathrm{~A}^{-1-}$ mice, certain TCR $\gamma \delta \mathrm{T}$-cell subsets are lacking, owing to an impaired ability to rearrange particular $T C R G$ and TCRD gene segments. ${ }^{15}$ Targeted disruption of the HEB gene gives rise to a partial block in early T-cell differentiation prior to the development of double-positive cells. ${ }^{24}$

It is now generally accepted that $\mathrm{V}(\mathrm{D}) \mathrm{J}$ recombination processes are also involved in the formation of particular chromosome aberrations in human leukemias. ${ }^{25-27}$ This especially concerns aberrations in human T-ALL, in which TCRB or TCRD gene segments are translocated to oncogenes, resulting in activation of these oncogenes through TCR regulatory elements. ${ }^{28}$ Although little is known about the exact molecular processes, it is tempting to speculate that transcription factor-induced accessibility of the involved loci is a critical step in the formation of these aberrations.

Here we show that 2 types of E proteins, E2A and HEB, have the ability to target the recombination machinery to TCR loci in nonlymphoid cells. Expression of E2A or HEB in the presence of RAG1/RAG2 appeared to induce immature types of $T C R D$ rearrangements, several $T C R G$ rearrangements, but no $T C R B$ recombination.

\section{Materials and methods}

\section{Cell culture}

Nonlymphoid BOSC 23 cells were cultured in Dulbecco modified Eagle medium with $10 \%$ fetal bovine serum at $37^{\circ} \mathrm{C}$ with $5 \% \mathrm{CO}_{2} .{ }^{29}$

\section{DNA constructs}

The E12 and E47 variants of the human E2A transcription factor gene were cloned into the $\mathrm{pH} \beta \mathrm{APneo}$ vector, which has been previously described ${ }^{30}$ The human HEB transcription factor gene was cloned in the pXS vector, which is derived from pcDL-Sra296. ${ }^{31}$ The pEBB-Rag1 and pEBB-Rag2 expression vectors have been described before. ${ }^{32}$

\section{Transfection protocol}

Transfections were performed via calcium phosphate precipitation as described. ${ }^{23}$ BOSC 23 cells were plated on the day prior to transfection at a density of $4.5 \times 10^{6}$ cells per 10 -cm dish. On the day of the transfection, 18 to $24 \mu \mathrm{g}$ total DNA, including $6 \mu \mathrm{g}$ each expression vector or carrier DNA, was used per transfection. The cells were harvested 3 days after transfection.

\section{Polymerase chain reaction analysis of TCR rearrangements (coding and signal joints)}

By polymerase chain reaction (PCR), $200 \mathrm{ng}$ genomic DNA, isolated from the various BOSC 23-transfected cell cultures, was analyzed in a 50- $\mathrm{LL}$ reaction volume containing $1 \times$ Taq Gold buffer (Applied Biosystems, Foster City, CA), $1.5 \mathrm{mM} \mathrm{MgCl}_{2}, 12.5 \mathrm{pmol}$ each primer, $200 \mu \mathrm{M}$ deoxy-nucleoside 5' triphosphate, and $1 \mathrm{U}$ AmpliTaq Gold (Applied Biosystems). PCR reactions were performed on an ABI480 machine as follows: 10 minutes preactivation at $94^{\circ} \mathrm{C}, 40$ cycles of 45 seconds at $94^{\circ} \mathrm{C}$, 90 seconds at $60^{\circ} \mathrm{C}, 2$ minutes at $72^{\circ} \mathrm{C}$, followed by a 10 -minute extension at $72^{\circ} \mathrm{C}$. The primers used to detect $T C R D$ rearrangements as well as their circular excision products locus are listed in Table 1. TCRG gene rearrangements were studied with the use of V $\gamma \mathrm{I}-3^{\prime}, \mathrm{V} \gamma \mathrm{II}-3^{\prime}, \mathrm{V} \gamma \mathrm{III}-3^{\prime}$, V $\gamma \mathrm{IV}-3^{\prime}, \mathrm{J} \gamma 1.1 / 2.1-3^{\prime}, \mathrm{J} \gamma 1.2-3^{\prime}$, and $\mathrm{J} \gamma 1.3 / 2.3-3^{\prime}$ primers. ${ }^{33} T C R B$ analysis was performed with $\mathrm{V} \beta 2$ and $\mathrm{V} \beta 5 \mathrm{~A}$ family primers (A.W.L., unpublished data, 2001) or D $\beta 1$ and D $\beta 2$ primers (T. Szczepanski, unpublished results, 2001) in combination with $\mathrm{J} \beta 1(2)$ and $\mathrm{J} \beta 2(2)$ primers. $^{34}$ Deletional rearrangements in the TCRD locus were studied with the use of $\delta$ REC-3' and $\psi \mathrm{J} \alpha-3^{\prime}$ primers (Table 1$){ }^{35}$ In all reactions, proper positive controls for the various types of TCR rearrangements were included: well-defined leukemic cell DNA and/or total thymus DNA. We used mock-transfected BOSC 23 cells and/or HeLa genomic DNA as template containing negative controls. We analyzed $20 \mu \mathrm{L}$ each PCR on a $2 \%$ agarose gel, followed by ethidium bromide staining. If TCR rearrangements were detected in the agarose gels, the remainder of the PCR products were subjected to heteroduplex analysis to discriminate between monoclonal and polyclonal rearrangements. ${ }^{36}$ In short, heteroduplex analysis consisted of 5 minutes denaturation at $94^{\circ} \mathrm{C}$ and 60 minutes renaturation at $4^{\circ} \mathrm{C}$ prior to electrophoresis on $6 \%$ nondenaturing polyacrylamide gels (polyacrylamide to bisacrylamide, 29:1) in $0.5 \times$ TBE buffer. ${ }^{36}$ Ethidium bromide-stained homoduplex or heteroduplex PCR products were visualized with UV light.

\section{Cloning of PCR products and sequencing}

Following amplification, PCR products were purified by means of QIAquick PCR purification kits (Qiagen, Hilden, Germany) and cloned into pGEM-T Easy vector (Promega, Madison, WI) according to the manufacturer's instructions. Clones containing insert were sequenced on the ABI377 fluorescent sequencer, by means of the dye terminator cycle sequencing kit and AmpliTaq FS (Applied Biosystems). ${ }^{7}$

\section{Real-time quantitative PCR of TCR rearrangements}

Levels of particular rearranged TCRD and TCRG PCR products were quantified by real-time quantitative (RQ) PCR, by means of TaqMan technology on the ABI Prism 7700 Sequence Detection System (Applied Biosystems), as described earlier. ${ }^{37-39}$ To this end, forward (F-DD2-KLON, F-VG8-KLON) and reverse primers (R-DD3-CONS4, R-JG13/23-KLON) (Table 1) were designed by means of Primer Express (Applied Biosystems) and Oligo6.2 (Dr W. Rychlik, Molecular Biology Insights, Cascade, CO) software to select melting temperature values of $58^{\circ} \mathrm{C}$ to $60^{\circ} \mathrm{C}$ and to exclude hairpin formation, dimer formation, and false priming. Design of the primers was performed so that the primers could be used with already present dual-labeled TaqMan probes (T-DD3-CONS2, T-JG13/23CONS3) (Table 1). An albumin primer/probe RQ-PCR set (Applied Biosystems) was used to quantitate and normalize the amount of DNA used in the various transfections. ${ }^{37}$

\section{Results}

E2A and HEB induce incomplete TCRD gene rearrangements in nonlymphoid cells

To study the effect of E-box proteins on recombination events in the various human TCR loci, we employed the model system described by Romanow et al. ${ }^{23}$ Nonlymphoid BOSC 23 cells, which harbor their TCR loci in germline configuration, were transfected with E2A, splice variants (E12 or E47), or HEB, either alone or in combination with the RAG1/RAG2 proteins. PCR analysis of genomic DNA, isolated 3 days posttransfection, was performed by means of specific primers for the most frequently occurring types of incomplete and complete TCRD gene rearrange-

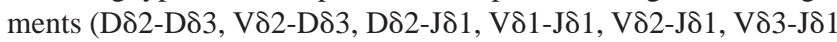
recombinations) (Figure 1A). Transfection of E2A or HEB alone, or mock transfection, did not result in activation of any of these rearrangements. However, D $\delta 2-D \delta 3$ and V $\delta 2-D \delta 3$ rearrangements were clearly induced upon transfection of either E2A or HEB in 
Table 1. Primers and probes used for polymerase chain reaction amplification of TCRD rearrangements and real-time quantitative polymerase chain reaction

\begin{tabular}{|c|c|c|}
\hline Primer & Sequence $\left(5^{\prime}-3^{\prime}\right)$ & Reference \\
\hline \multicolumn{3}{|l|}{ Coding joint PCR } \\
\hline V $\delta 1-5^{\prime \prime \prime \prime \prime}$ & ACT CAA GCC CAG TCA TCA GTA TCC & 33 \\
\hline V $\delta 2-5^{\prime}$ & ACC AAA CAG TGC CTG TGT CAA TAG G & 33 \\
\hline V83-5' & GAC CAG ACG GTG GCG AGT GGC & 33 \\
\hline Ds2-5' RO2 & CCA CAT TGG GAG TGT CAA CAT TT & This study \\
\hline D $\delta 3-3^{\prime} \mathrm{N}$ & CTT CCT GCT ATC CCT TCC AGG & 33 \\
\hline D $83-5^{\prime}$ & CGC GTC GAC CAT ATA GTG GAA ACC GAG GGG & This study \\
\hline J $\delta 1-3^{\prime}$ & ACC TCT TCC CAG GAG TCC TCC & 33 \\
\hline Ј $\delta 3-3^{\prime}$ & CGC GTC GAC TCA AAT TAT CCC AGA AAT ATA GG & 44 \\
\hline$\delta$ REC-3' & GCA ACA TCA CTC TGT GTC TAG C & 35 \\
\hline$\psi \mathrm{J} \alpha-3^{\prime}$ & CCT GAA GCT TAA GGC ACA TTA GAA TCT CTC ACT G & 35 \\
\hline \multicolumn{3}{|l|}{ Signal joint PCR } \\
\hline V82-sj 3' & CTG GTC AGT GGT TTT TGA GCT GCT & This study \\
\hline $\mathrm{D} \delta 2-5^{\prime} \mathrm{XBg}$ & GTA GAT CTA GAA GAG GGT TTT TAT ACT GAT GTG & This study \\
\hline Ds2-lower & TCC CAA TGC TGA GAC ATA CAT & This study \\
\hline D $83-5^{\prime} S$ & CGC GTC GA CCA TAT AGT GTG AAA CCG AGG GG & This study \\
\hline $\mathrm{D} \delta 3-3^{\prime} \mathrm{N}$ & CTT CCT GCT ATC CCT TCC AGG & 33 \\
\hline J81 sj 5' & GTC CCT ACC TGC AGA TGA TTA ACC & This study \\
\hline J反3 sj 5' & CCC TTG GTC TCA TCA AGA GCA GC & This study \\
\hline \multicolumn{3}{|l|}{ Real-time PCR } \\
\hline F-DD2-KLON & GAA GAA GAG GGT TTT TAT ACT GAT GTG TT & This study \\
\hline R-DD3-CONS4 & TTG CCC CTG CAG TTT TTG TAC & This study \\
\hline T-DD3-CONS2 & ATA CGC ACA GTG CTA CAA AAC CTA CAG AGA CCT & This study \\
\hline F-VG8-KLON & TCT ATT ACT GTG CCA CCT GGG ATA & This study \\
\hline R-JG13/23-KLON & TTC CTG CCT TCC CTC TAT TAC CTT & This study \\
\hline T-JG13/23-CONS3 & TGT CAC AGG TAA GTA TCG GAA GAA TAC AAC ATT TCC & This study \\
\hline
\end{tabular}

PCR indicates polymerase chain reaction; sj, signal joint.

combination with the $2 R A G$ genes (Figure 1B-C). In contrast to V82-D 83 rearrangements, D $\delta 2-D \delta 3$ recombination products were also detectable in transfectants with the 2 RAG genes only. However, quantification by RQ-PCR with the TaqMan technology revealed that the D $\delta 2-D \delta 3$ rearrangement levels were essentially higher (5- to 10-fold) in the HEB-plus-RAG transfectants than in the RAG1/RAG2only transfectants. Further cloning and sequencing of the PCR products from the various transfectants showed heterogeneous V82-D 83 junctional regions in all transfection combinations, with variable numbers of deleted nucleotides at both sides and occasionally introduction of palindromic $(\mathrm{P})$ nucleotides (Table 2). Strikingly, virtually all sequenced D $82-\mathrm{D} \delta 3$ rearrangements of the transfected cells were found to be identical, showing complete deletion of the $\mathrm{D} \delta 2$ and $\mathrm{D} \delta 3$ gene segments and direct coupling of the upstream RSS of the D $\delta 2$ segment to the downstream RSS of the D $\delta 3$ segment (Table 2, Figure 2). This so-called signal joint, which is normally present in excision circles, was only occasionally found in normal thymocytes (Table 2, Figure 2).

In contrast to the $\mathrm{D} \delta 2-\mathrm{D} \delta 3$ and V $\delta 2-\mathrm{D} \delta 3$ rearrangements, we did not

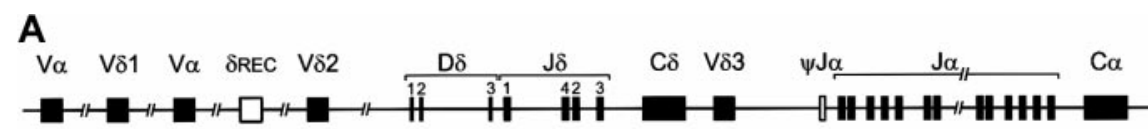

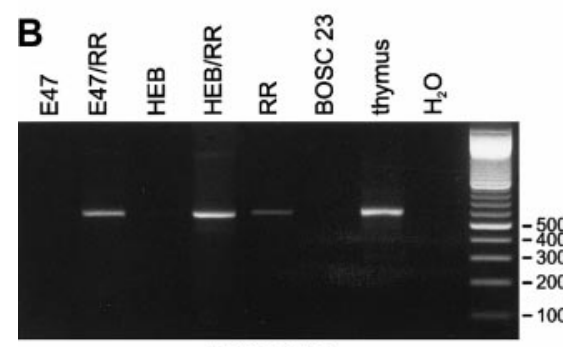

$\mathrm{D} \delta 2-\mathrm{D} \delta 3$

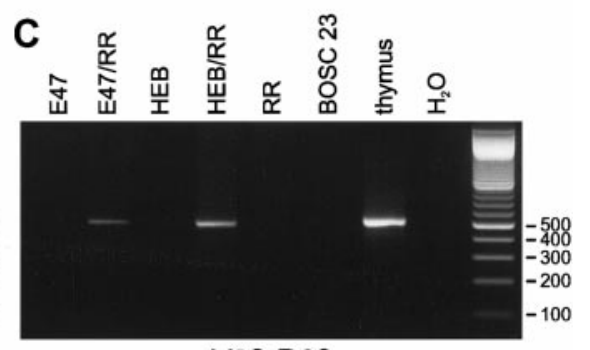

V $\delta 2-D \delta 3$

Figure 1. Induction of TCRD recombination by E2A or HEB in the presence of RAG1 and RAG2. Both E2A and HEB in combination with RAG1 and RAG2 have the ability to induce TCRD recombination in nonlymphoid cells. (A) Schematic diagram of the human TCRD/TCRA locus. Presented are the V $\delta$, D $\delta$, and J $\delta$ gene segments that are positioned between the $V_{\alpha}$ and $J \alpha-C \alpha$ regions in the TCRA locus. The $\delta R E C$ and $\psi \mathrm{J} \alpha$ gene segments that flank the TCRD locus are involved in deletion of the TCRD gene prior to TCRA recombinations. (B) (C) BOSC 23 cells were transfected with E47, HEB, RAG1, and RAG2 expression vectors. Following genomic DNA isolation, 200 ng DNA of the various transfectants was used for PCR amplification by means of D $\delta 2-5^{\prime}$ RO2 plus D $\delta 3-3^{\prime} \mathrm{N}$ (panel B) or V $\delta 2-5^{\prime}$ plus D $\delta 3-3^{\prime} \mathrm{N}$ (panel C) primers, which are used for specific detection of D $\delta 2-D \delta 3$ and V82-D $\delta 3$ rearrangements, respectively. Thymus DNA was used as positive control, and mock-transfected BOSC 23 as nonspecific template control. PCR products were run on a $2 \%$ agarose gel and stained with ethidium bromide. Rearranged D $\delta 2-D \delta 3$ and V $\delta 2-D \delta 3$ PCR products were observed upon combined transfection

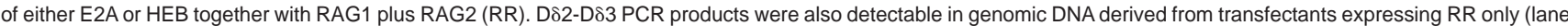
$R R$ ), though at much lower levels as quantitated via RQ-PCR (see "Results"). 
Table 2. Sequences of cloned TCRD recombination products

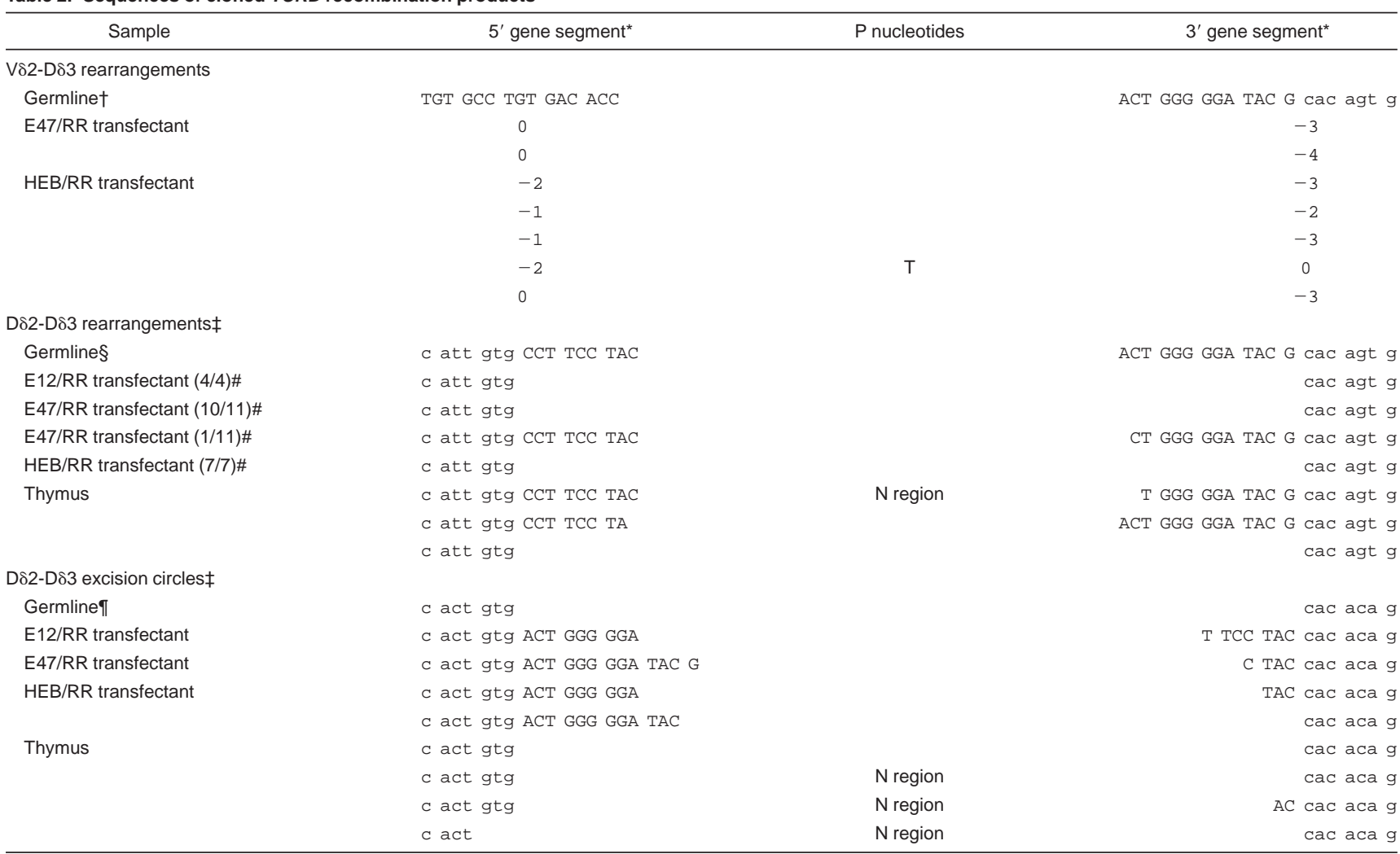

RSS indicates recombination signal sequence; RR, RAG1 plus RAG2.

*Indicated are the number of nucleotides deleted at the 5' and 3' gene segments. Lower case represents RSS nucleotides; upper case, nucleotides of gene segments. †For 5' gene segment, this is V $\delta 2$ (coding); for $3^{\prime}$ gene segment, this is D $\delta 3$ (coding $+3^{\prime}$ RSS).

¥See Figure 2 for the D $\delta 2-D \delta 3$ rearrangement and excision circle composition, such as they occur in the classical and alternative recombination mechanisms.

SFor 5' gene segment, this is D $\delta 2$ (5' RSS + coding); for 3' gene segment, this is D $\delta 3$ (coding + 3' RSS).

IFor 5' gene segment, this is D $\delta 3$ (5' RSS); for 3' gene segment, this is D $\delta 2$ (3' RSS).

\#Indicated are the number of PCR products of the total number of sequenced PCR products.

detect the other 4 frequently occurring types of TCRD rearrangements, which all involve the J $\delta 1$ gene segment (Table 3). D $82-\mathrm{D} \delta 3$ recombinations can be formed only by direct rearrangement of the 2 neighboring D 82 and D 83 segments. The intermediate circular excision products or signal joints that are formed as a side product during this process (Figure
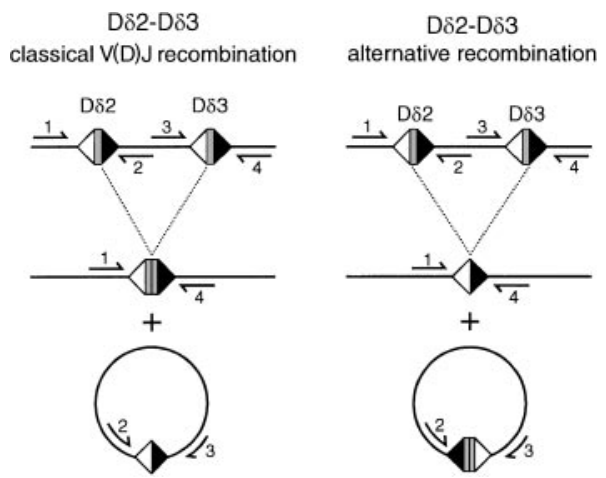

Figure 2. Scheme of classical V(D)J recombination and alternative recombina-

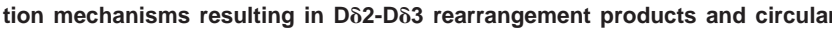
excision products. In classical recombination, $\mathrm{D} \delta 2$ and D $\delta 3$ coding sequences are coupled to a coding joint, whereas the intervening sequence is coupled via the downstream D 82 RSS and the upstream D 83 RSS to a signal joint on the circular excision product. In the alternative mechanism that was observed in the transfected BOSC 23 cells on the basis of the sequencing of the rearrangements, a signal joint of

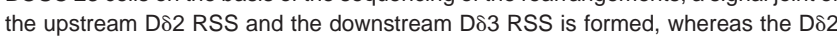
and D $\delta 3$ coding sequences are deleted out on the excision circles. Primers

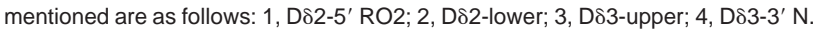

$3 \mathrm{~A}$ ) were indeed detected in the same transfection combinations (E2A or HEB plus RAG) in which the corresponding D $\delta 2-D \delta 3$ coding joints were found (Figure 3B). Sequencing of these excision circle products from transfected cells showed a coding joint-like configuration, confirming the less common mechanism of D $82-\mathrm{D} \delta 3$ recombination (Table 2; Figure 2); similar products were occasionally found in thymocytes as well. V $\delta 2-D \delta 3$ rearrangements can be formed either by direct coupling or via a 2-step mechanism involving the D $\delta 2-D \delta 3$ joint as an intermediate. In the former case, V $82-\mathrm{D} \delta 3$ signal joints should be detectable, whereas in the latter option both the D $\delta 2-D \delta 3$ signal joints as well as V82-D 22 signal joints should be observed. PCR analysis did show V82-D83 signal joints in the E2A or HEB plus RAG transfectants (Figure 3A,C), whereas V82-D 22 signal joints were not found, indicating that the observed V82-D 83 recombination takes place via direct coupling of the 2 gene segments, rather than as a 2-step process in which D82-D 83 coding joints act as intermediates.

\section{TCRD recombination involving $\mathrm{J} \delta$ gene segments cannot be induced by E2A and HEB}

From various studies, it is known that $\mathrm{V} \delta$-J $\delta$ rearrangements are formed via multiple (consecutive) couplings involving D $\delta$ segments, rather than as a direct joining of $\mathrm{V} \delta$ to $\mathrm{J} \delta$ gene segments. This even applies to D $\delta 2-J \delta 1$ joints that are known to be formed in 2 steps, given the presence of identifiable D $\delta 3$ segment sequences in virtually all of these coding joints. ${ }^{40,41}$ To determine whether $\mathrm{E} 2 \mathrm{~A}$ or HEB can induce recombination to $\mathrm{J} \delta 1$, we studied a rarer 
Table 3. TCRD rearrangements in various E2A- or HEB-transfected BOSC 23 cells

\begin{tabular}{|c|c|c|c|c|c|c|c|c|c|}
\hline Rearrangement & E47 & E47/RR & E12 & E12/RR & HEB & HEB/RR & $\mathrm{RR}$ & BOSC-23* & Thymus \\
\hline D $\delta 2-D \delta 3$ & - & + & - & + & - & + & $+1-$ & - & ++ \\
\hline 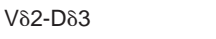 & - & + & - & + & - & + & - & - & ++ \\
\hline 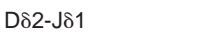 & - & - & - & - & - & - & - & - & ++ \\
\hline V反1-Jס1 & - & - & - & - & - & - & - & - & ++ \\
\hline 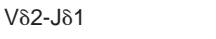 & - & - & - & - & - & - & - & - & ++ \\
\hline 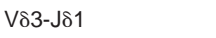 & - & - & - & - & - & - & - & - & ++ \\
\hline 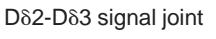 & - & + & - & + & - & + & $+1-$ & - & ++ \\
\hline 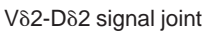 & - & - & - & - & - & - & - & - & ++ \\
\hline 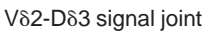 & - & + & - & + & - & + & - & - & ++ \\
\hline 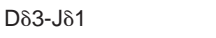 & - & - & - & - & - & - & - & - & ++ \\
\hline 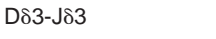 & - & - & - & - & - & - & - & - & ++ \\
\hline 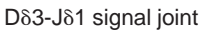 & - & - & - & - & - & - & - & - & ++ \\
\hline 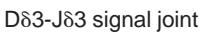 & - & - & - & - & - & - & - & - & ++ \\
\hline
\end{tabular}

RR indicates RAG1 plus RAG2.

*In some experiments, GFP-transfected cells were used as nonspecific template control.

type of TCRD rearrangement, D $\delta 3-\mathrm{J} \delta 1$, which can occur only as a direct coupling and which is known to be present in human thymocytes (T. M. Breit et al, unpublished observations, 2001). Although readily detectable in thymocytes, this rearranged D $\delta 3$ $\mathrm{J} \delta 1$ product could not be detected in any of the transfected cell populations; the only PCR product apparent was the larger germline fragment encompassing the nonrearranged $\mathrm{D} \delta 3$ and $\mathrm{J} \delta 1$ segments that lie within $1 \mathrm{~kb}$ (Table 3 ). Even after nested PCR, no

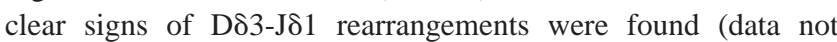
shown), and also no D $\delta 3-J \delta 1$ signal joints were detectable (Table 3 ). To fully exclude recombination to J $\delta$ gene segments, we studied another type of TCRD rearrangement, $\mathrm{D} \delta 3 \mathrm{~J} \delta 3$, which is also formed in a 1-step reaction and occurs in thymocytes as well. Also this type of coupling (either coding joint or signal joint) could not be observed in any of the transfected combinations (Table 3). Collectively, these data illustrate that E2A and HEB have the ability to induce recombination in the TCRD locus, but that this concerns only 1-step rearrangements in the $\mathrm{V} \delta 2-\mathrm{D} \delta$ region, and not in the more downstream $\mathrm{J} \delta$ region.

\section{V-J rearrangements in the TCRG locus are induced by E2A and HEB in cooperation with the RAG proteins}

Although the TCRD locus is generally believed to be the first TCR locus that is rearranged during T-cell differentiation, we wished to ascertain whether in the transfected BOSC 23 cells recombination events would also be detectable in the TCRG locus, which starts rearranging later than $T C R D$ during thymocyte differentiation, but earlier than the TCRB and TCRA genes. ${ }^{9-11}$ The human TCRG locus is composed of a limited set of $\mathrm{V} \gamma$ gene segments that are grouped in $\mathrm{V} \gamma$ families and $5 \mathrm{~J} \gamma$ gene segments clustered in the homologous $\mathrm{J} \gamma 1$ and $\mathrm{J} \gamma 2$ regions (Figure 4A). To analyze $\mathrm{V} \gamma-\mathrm{J} \gamma$ recombinations, we employed $4 \mathrm{~V} \gamma$ family primers in combination with 3 primers known to recognize the $\mathrm{J} \gamma 1.1 / 2.1$, J $\gamma 1.2$, and $\mathrm{J} \gamma 1.3 / 2.3$ segments. V $\gamma \mathrm{I}-\mathrm{J} \gamma 1.3 / 2.3$ products were found to be induced by the basic HLH (bHLH) proteins E2A or HEB in the presence of RAG proteins as compared with RAG proteins only (Figure 4B). Similar

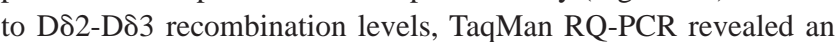
inducing effect (3- to 5-fold) in the E2A or HEB plus RAG

A

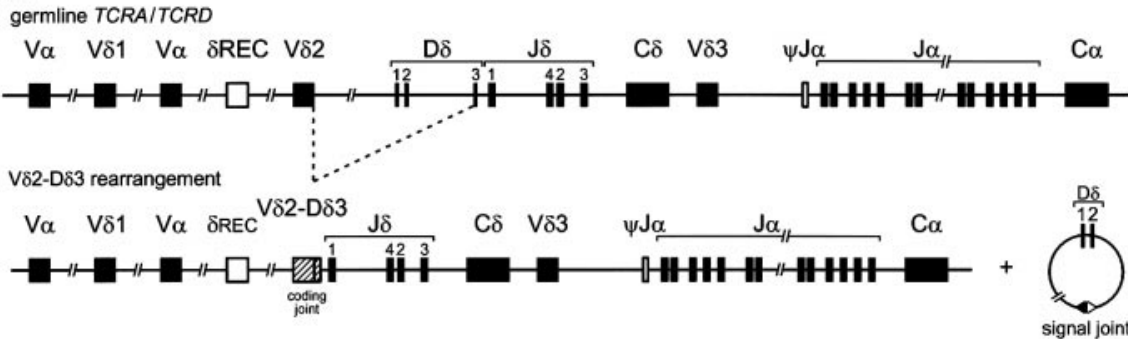

B

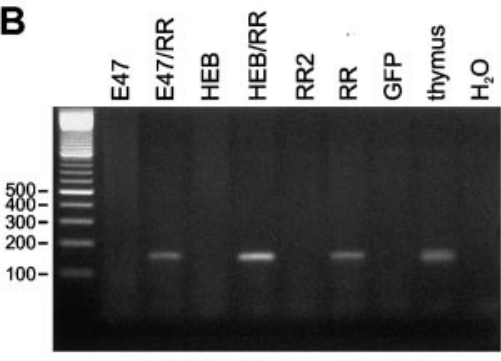

D $\delta 2-D \delta 3$ signal joint

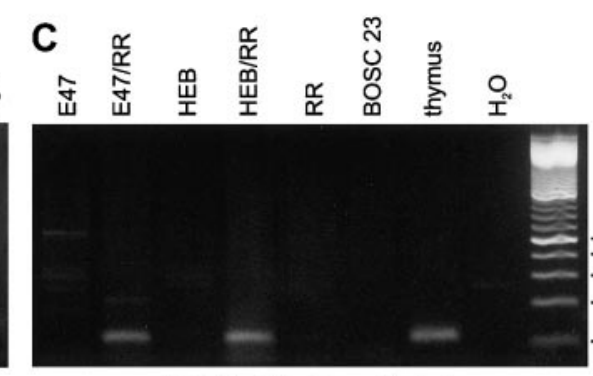

V $\delta 2-D \delta 3$ signal joint
Figure 3. Analysis of intermediate excision circles or signal joints. Analysis of intermediate excision circles or signal joints illustrates that E2A and HEB induce singlestep TCRD recombinations in nonlymphoid cells. (A) In the example of a V $\delta 2-D \delta 3$ rearrangement, the coding and signal joints formed during direct coupling of the V $\delta 2$ and D $\delta 3$ segments are shown. $(B, C)$ Analysis of signal joints in BOSC 23 cells transfected with E47, HEB, RAG1, and RAG2 expression vectors. Genomic DNA (200 ng) of the various transfectants was used for PCR amplification by

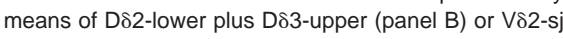
3' plus D $83-5$ ' S (panel C) primers that specifically detect D $\delta 2-D \delta 3$ and V $\delta 2-D \delta 3$ signal joints, respectively. Thymus DNA was used as positive control, and GFP- or mock-transfected BOSC 23 DNA as nonspecific template control. PCR products were run on a $2 \%$ agarose gel and stained with ethidium bromide. Similar to the coding joints shown in Figure 1, D $\delta 2-D \delta 3$ and V $\delta 2-D \delta 3$ signal joints were observed upon combined transfection of either E47 or HEB together with RR. In line with the data on D $\delta 2-D \delta 3$ $\mathrm{PCR}$ products, D $\delta 2-\mathrm{D} \delta 3$ signal joints were also detectable in genomic DNA derived from transfectants expressing $R R$

-500 only (lane RR). Importantly, transfection with $2 \mu \mathrm{g}$ RAG -300 expression vectors (lane RR2) did not result in detectable -200 signal joints; this amount of RAG1/RAG2 vector leads to RAG activity levels that are more in line with the RAG activity levels in those cases in which $6 \mu \mathrm{g}$ RAG1/RAG2 is cotransfected with E2A or HEB (W. J. Romanow, personal communication, 2001). 


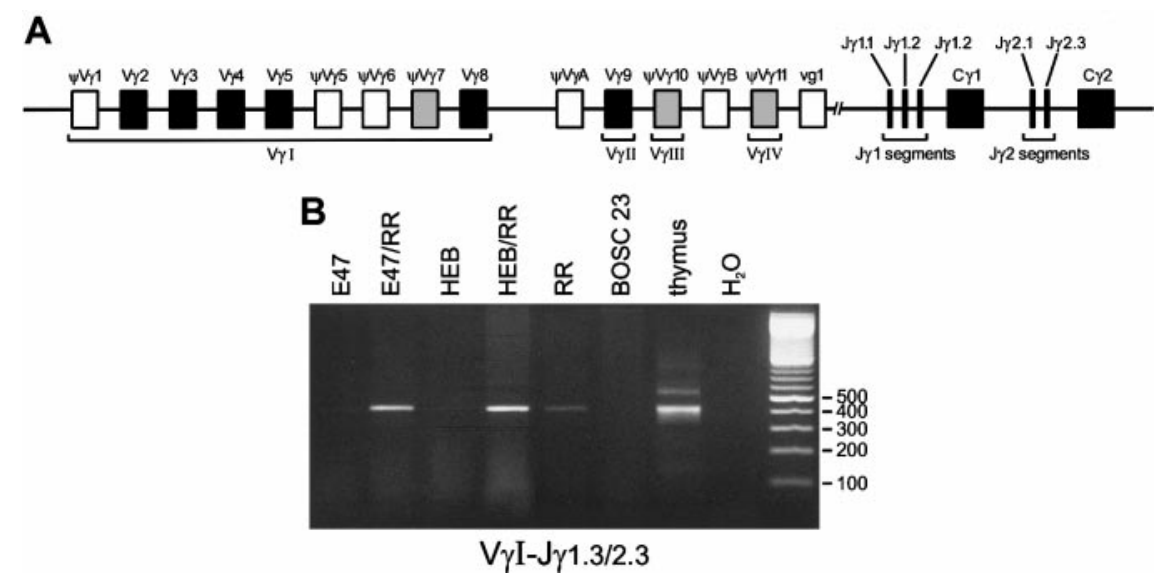

Figure 4. Induction of $\mathbf{V}_{\boldsymbol{\gamma}}-\mathrm{J} \gamma$ rearrangements by E2A or HEB in the presence of RAG1 and RAG2. (A) Schematic diagram of the human TCRG locus. The human TCRG locus comprises 2 constant region gene segments $(C \gamma)$ preceded by 2 or 3 joining gene segments $(J \gamma)$ and at least 14 variable gene segments $(V \gamma)$ belonging to 4 subgroups. Nine $V \gamma$ gene segments ( 5 functional genes and 4 pseudogenes) belong to subgroup I, whereas subgroups II, III, and IV each consist of a single gene segment designated $\mathrm{V} \gamma \mathrm{9}$, $V_{\gamma} 10$, and $V_{\gamma} 11$, respectively. Two pseudogenes, $V_{\gamma} A$ and $V_{\gamma} B$, located upstream of $V_{\gamma} 9$ and $V_{\gamma} 11$, respectively, belong to none of these subgroups. Five joining segments have been identified: $J_{\gamma} 1.1, J \gamma 1.2$, and $J \gamma 1.3$ upstream of $C \gamma 1$; and $J \gamma 2.1$ and $J \gamma 2.3$ upstream of $C \gamma 2$. In addition to the 6 functional $V \gamma$ gene segments (solid blocks), 3 pseudogenes (shaded blocks) can also rearrange to $\mathrm{J} \gamma$ gene segments. (B) Following transfection of BOSC 23 cells, PCR amplification with 200 ng genomic DNA of the transfected cells was performed by means of $\mathrm{V} \gamma \mathrm{I}-3^{\prime}$ - and $\mathrm{J} \gamma 1.3 / 2.3-3^{\prime}-$ specific primers. Thymus DNA and BOSC 23 DNA were used as positive and nonspecific template controls, respectively. Electrophoresis of PCR products on $2 \%$ agarose gels shows that E47 or HEB and RAG1 plus RAG2 proteins can promote $V \gamma \mathrm{\gamma}-\mathrm{J} \gamma 1.3 / 2.3$ rearrangements at high levels as compared with transfectants expressing RR only (lane RR) as quantitated by RQ TaqMan PCR analysis.

transfectants as compared with transfections with the RAG genes alone. Heteroduplex analysis of the $\mathrm{V} \gamma$-J $\gamma$ PCR products to discriminate between polyclonal and clonal recombination products revealed some level of heterogeneity in the various transfection combinations (data not shown). Since the $V \gamma I$ gene family consists of many distinct $\mathrm{V} \gamma$ gene segments that can rearrange, we sequenced these $\mathrm{V} \gamma \mathrm{I}-\mathrm{J} \gamma 1.3 / 2.3$ recombinations to study the diversity of V gene segment usage (Table 4). All (approximately 20) sequenced products were found to contain the J $\gamma 2.3$ gene segment, which is discernible from $\mathrm{J} \gamma 1.3$ at a single nucleotide position. At the $\mathrm{V}$ side, 2 gene segments were identified: $\psi \mathrm{V} \gamma 7$ and $\mathrm{V} \gamma 8$. Interestingly, within the $\mathrm{V} \gamma \mathrm{I}$ cluster, these 2 segments are most proximal to the $\mathrm{J} \gamma$ segments (Figure $4 \mathrm{~A}$ ), which might explain their predominance. Rearrangements between V $\gamma \mathrm{IV}(\mathrm{V} \gamma 11)$ and $\mathrm{J} \gamma 1.3 /$ 2.3 gene segments were also observed in the E2A or HEB plus RAG transfectants, but they could be found at similar levels in the RAG1/RAG2 alone transfectants (data not shown). Apparently, the $\mathrm{V} \gamma \mathrm{IV}$ and $\mathrm{J} \gamma 2.3$ gene segments are relatively easily accessible to the action of the RAG proteins, even without the presence of lymphoid transcription factors. The position of the V $\gamma \mathrm{IV}$ gene segment just proximal to the $\mathrm{J} \gamma$ gene segments might explain the finding of the otherwise rare $\mathrm{V} \gamma \mathrm{IV}-\mathrm{J} \gamma 1.3 / 2.3$ recombination. Never- theless, rearrangements between the V $\gamma \mathrm{IV}$ segment and the more proximal $\mathbf{J} \gamma$ segments ( $\mathrm{J} \gamma 1.1$ and $\mathbf{J} \gamma 2$.1) were not seen. Moreover, recombination products between any of the other $\mathrm{V} \gamma$ gene segments and these $\mathrm{J} \gamma 1.1$ and $\mathrm{J} \gamma 2.1$ segments were not detectable at all in the BOSC 23 transfectants. The same was true for $\mathrm{V} \gamma$ 9-J $\gamma 1.2$ rearrangements, which are frequently found in peripheral blood $\mathrm{TCR} \gamma \delta^{+} \mathrm{T}$ cells. The E2A and HEB bHLH proteins thus not only induce $T C R D$ recombination, but also direct the RAG proteins to rearrange particular $\mathrm{V}$ and $\mathrm{J}$ gene segments within the $T C R G$ locus.

\section{Absence of TCRB rearrangements and TCRD deletions in E2A and HEB transfectants}

To further analyze potential effects of E2A and/or HEB on V(D)J recombination in the TCR loci that are normally rearranged in later stages of T-cell differentiation (late double-negative and immature single-positive stages), we first studied rearrangements in the human TCRB locus. Unlike the TCRG locus, the TCRB locus is built up of a large number of distinct $V \beta$ segments, clustered in approximately $25 \mathrm{~V} \beta$ families, and $2 \mathrm{D} \beta$ segments each lying upstream of a cluster of 6 or $7 \mathrm{~J} \beta$ gene segments. The presence of $\mathrm{V}$, $\mathrm{D}$, and $\mathrm{J}$ segments in the TCRB locus implies that both incomplete

Table 4. Sequences of cloned TCRG recombination products

\begin{tabular}{|c|c|c|c|c|c|c|c|c|c|}
\hline & \multicolumn{3}{|c|}{$\mathrm{E} 12 / \mathrm{RR}$} & \multicolumn{3}{|c|}{$\mathrm{E} 47 / \mathrm{RR}$} & \multicolumn{3}{|c|}{ HEB/RR } \\
\hline & $5^{\prime}$ del & $\mathrm{P}$ region & $3^{\prime}$ del & $5^{\prime}$ del & $\mathrm{P}$ region & $3^{\prime}$ del & $5^{\prime}$ del & $\mathrm{P}$ region & $3^{\prime}$ del \\
\hline \multicolumn{10}{|l|}{ V $\gamma 7-J \gamma 2.3$ rearrangement } \\
\hline & 0 & C & -4 & -2 & & 0 & 0 & $\mathrm{CC}$ & -7 \\
\hline & -2 & & 0 & & & & -9 & & -4 \\
\hline \multicolumn{10}{|l|}{ Vy8-J 2.3 rearrangement } \\
\hline & -3 & & -15 & -1 & & 0 & 0 & C & -7 \\
\hline & -5 & & -2 & -2 & C & 0 & -2 & & -4 \\
\hline & -5 & & -3 & & & & -4 & & -4 \\
\hline & & & & & & & -4 & & -2 \\
\hline & & & & & & & -6 & & 0 \\
\hline
\end{tabular}

RR indicates RAG1 plus RAG2.

Indicated are the number of nucleotides deleted at the $5^{\prime}$ and $3^{\prime}$ gene segments. 
and complete rearrangements can occur. Incomplete TCRB rearrangements almost exclusively concern $\mathrm{D} \beta-\mathrm{J} \beta$ recombinations, as incomplete $\mathrm{V} \beta-\mathrm{D} \beta$ joints are rarely found in $\mathrm{T}$ cells. For this reason, we studied $D \beta 1-\mathrm{J} \beta 1, D \beta 1-\mathrm{J} \beta 2$, and $\mathrm{D} \beta 2-\mathrm{J} \beta 2$ rearrangements, which can readily be detected in thymocytes. However, we could not find either one of these products in any of the transfected cell populations, even after nested PCR reactions (data not shown). Given these results and also the results from the TCRD analysis concerning 2-step recombinations, we anticipated that $\mathrm{V} \beta-\mathrm{J} \beta$ joints, which normally include $\mathrm{D} \beta$ sequences, would not be detectable either. Employing $\mathrm{J} \beta 1$ or $\mathrm{J} \beta 2$ primers in combination with specific primers for the frequently used $V \beta 2$ and $V \beta 5$ families, ${ }^{42}$ we indeed could not observe complete $V \beta-J \beta$ joints (data not shown).

To further substantiate the absence of other mature TCR gene rearrangements, we studied TCRD deletional rearrangements mediated by the nonfunctional $\delta R E C$ and $\psi \mathrm{J} \alpha$ segments, which flank the coding elements of the TCRD locus (Figure 1). These TCRD deletions precede rearrangements in the human TCRA locus, and they are known to occur at a relatively late stage in T-cell differentiation. However, no $\delta$ REC- $\psi \mathrm{J} \alpha$ rearrangements were identified in transfected BOSC 23 cells (data not shown). Taken together, these data do not provide any evidence for a role for E2A or HEB in inducing TCRB rearrangements or TCRD deletional rearrangements.

\section{Discussion}

In this study, we provide evidence that the bHLH transcription factors E2A and HEB play a role in the induction of $\mathrm{V}(\mathrm{D}) \mathrm{J}$ recombination in human TCRD and TCRG loci, employing a transfection-based model of nonlymphoid cells. E2A and HEB were found to induce immature $\mathrm{D} \delta 2-\mathrm{D} \delta 3$ and $\mathrm{V} \delta 2-\mathrm{D} \delta 3$ rearrangements upon cotransfection with RAG proteins in nonlymphoid cells. Rearrangements of $\mathrm{V} \gamma \mathrm{I}$ family (especially $\psi \mathrm{V} \gamma 7$ and $\mathrm{V} \gamma 8$ ) gene segments to J $\gamma 2.3$ were also easily induced by the action of both transcription factors. All except the D $\delta 2-D \delta 3$ rearrangements were very similar to the majority of rearrangements found in lymphoid cells, with junctional regions characterized by nucleotide deletion and occasionally $\mathrm{P}$ nucleotides. The lack of $\mathrm{N}$ regions can be explained by the absence of terminal deoxynucleotidyl transferase, which mediates nontemplated nucleotide insertion. Remarkably, the junctions of virtually all D $\delta 2-D \delta 3$ rearrangements from the transfected cells were found to be identical, because of an unusual direct coupling of the intact upstream RSS of the D $\delta 2$ segment to the intact downstream RSS of the D 83 segment. This unusual type of rearrangement shares similarity to atypical $I G K$ gene recombinations between $\mathrm{J}_{\kappa}$ segments and an isolated RSSlike sequence in the $\mathrm{J}-\mathrm{C} \kappa$ intron. ${ }^{43}$ In fact, both types of recombinations represent signal joints, which normally are not found on the

Table 5. Detection of cloned TCRD, cloned TCRG, and cloned TCRB gene rearrangements in E2A/HEB-transfected cells as compared with human thymocytes and acute lymphoblastic leukemias

\begin{tabular}{|c|c|c|c|c|c|c|c|c|}
\hline \multirow[b]{2}{*}{ Rearrangement } & \multirow{2}{*}{$\begin{array}{c}\mathrm{E} 2 \mathrm{~A} / \mathrm{HEB} \\
\text { transfectants }\end{array}$} & \multicolumn{3}{|c|}{ Thymocytes } & \multicolumn{3}{|c|}{ T-ALL, \%* } & \multirow[b]{2}{*}{ Precursor B-ALL, \%* } \\
\hline & & $\mathrm{CD} 34^{+} 1 \mathrm{a}^{-}$ & $\mathrm{CD}_{3} 4^{+} 1 \mathrm{a}^{+}$ & Total & $\mathrm{CD}^{-}$ & $\mathrm{TCR}_{\gamma} \delta^{+}$ & $\operatorname{TCR} \alpha \beta^{+}$ & \\
\hline \multicolumn{9}{|l|}{$T C R D$} \\
\hline V反2-D $\delta 3$ & + & + & + & + & 6 & 4 & - & 67 \\
\hline D $\delta 2-J \delta 1$ & - & + & ++ & + & 10 & 15 & 7 & - \\
\hline V $\delta 1-J \delta 1$ & - & - & + & + & 24 & 56 & 13 & - \\
\hline 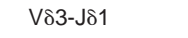 & - & - & + & + & 5 & 8 & 7 & - \\
\hline Other & NT & NT & NT & NT & 40 & 10 & 53 & 20 \\
\hline \multicolumn{9}{|l|}{$T C R G$} \\
\hline$V_{\gamma} I-J \gamma 1.1 / 2.1$ & - & NT & NT & + & 8 & 9 & 20 & 18 \\
\hline$V_{\gamma} \|-J \gamma 1.1 / 2.1$ & - & NT & NT & + & - & - & - & 1 \\
\hline$V_{\gamma} I I I-J \gamma 1.1 / 2.1$ & - & NT & NT & + & 1 & - & 1 & - \\
\hline$V_{\gamma} I \mathrm{~V}-\mathrm{J} \gamma 1.1 / 2.1$ & - & NT & NT & + & 1 & 4 & - & 1 \\
\hline$V_{\gamma} \|-J \gamma 1.2$ & - & NT & NT & + & 2 & - & - & - \\
\hline V $\gamma$ III-J $\gamma 1.2$ & NT & NT & NT & + & - & - & - & - \\
\hline V $\gamma \mid \mathrm{V}-\mathrm{J} \gamma 1.2$ & NT & NT & NT & + & - & - & - & - \\
\hline$V_{\gamma} \mid-J \gamma 1.3 / 2.3$ & + & - & + & + & 69 & 52 & 58 & 56 \\
\hline Vyll-Jy1.3/2.3 & - & - & + & + & 7 & 24 & 6 & 18 \\
\hline V $\gamma \| I I-J \gamma 1.3 / 2.3$ & - & - & + & + & 4 & 7 & 9 & - \\
\hline V $\gamma \mathrm{IV}-\mathrm{J} \gamma 1.3 / 2.3$ & $+1-$ & - & + & + & 4 & 4 & 5 & 5 \\
\hline Other & NT & NT & NT & NT & 4 & 1 & - & - \\
\hline \multicolumn{9}{|l|}{ TCRB } \\
\hline$D \beta 1-J \beta 1$ & - & - & + & + & 12 & 16 & 9 & - \\
\hline$D \beta 1-J \beta 2$ & - & - & + & + & 4 & 14 & 3 & 16 \\
\hline$D \beta 2-J \beta 2$ & - & - & + & + & 11 & 5 & 17 & 17 \\
\hline$V \beta-J \beta 1$ & - & - & - & + & 18 & 13 & 28 & - \\
\hline V $\beta-J \beta 2$ & - & - & - & + & 47 & 45 & 30 & 53 \\
\hline Other & NT & NT & NT & NT & 9 & 7 & 13 & 14 \\
\hline
\end{tabular}

Data on thymocytes and acute lymphoblastic leukemia compiled from Southern blot and/or polymerase chain reaction data from this study and earlier reports from ou laboratory. $6,11,44,45,47$

T-ALL indicates T-lineage acute lymphoblastic leukemia; B-ALL, B-lineage ALL; TCR, T-cell receptor; TCRD, TCR ; TCRG, TCR $;$; TCRB, TCR $\beta$; NT, not tested.

*Frequencies defined as percentage of detected TCRD rearrangements (on the basis of TCRDJ1 probe hybridization), percentage of detected TCRG rearrangements, and percentage of TCRB rearrangements (involving both the $\mathrm{J} \beta 1$ and $\mathrm{J} \beta 2$ regions). 
genome, but rather on the excision circles that are formed during $\mathrm{V}(\mathrm{D}) \mathrm{J}$ recombination (see Figure 2).

The virtually identical patterns of TCR gene recombinations in both the E2A plus RAG- and the HEB plus RAG-transfected cells showed a striking similarity to the most immature types of rearrangements seen in human thymocyte subpopulations (Table 5). D $\delta 2-\mathrm{D} \delta 3$ and V $\delta 2-\mathrm{D} \delta 3$ rearrangements represent the earliest $T C R D$ rearrangements in thymocytes, being clearly detectable via Southern blot analysis next to D $\delta 2-\mathrm{J} \delta 1$ rearrangements in sorted cells of the most immature $\mathrm{CD} 34^{+} / \mathrm{CD} 1 \mathrm{a}^{-}$subset. ${ }^{11}$ In the $\mathrm{CD} 34^{+} /$ $\mathrm{CD}_{1} \mathrm{a}^{+}$fraction, complete V $\delta 1-\mathrm{J} \delta 1$ and $\mathrm{V} \delta 2-\mathrm{J} \delta 1$ rearrangements become more prominent. However, rearrangements to J $\delta$ segments, even simple single-step couplings like D $\delta 3-\mathrm{J} \delta 1$ and D $\delta 3-\mathrm{J} \delta 3$ as also seen in thymus, could not be induced in the transfected cells. $T C R G$ rearrangements involving $\mathrm{J} \gamma 1.3 / 2.3$ segments and TCRB rearrangements (most probably, incomplete $\mathrm{D} \beta-\mathrm{J} \beta$ joinings) were clearly detectable only in $\mathrm{CD} 34^{+} / \mathrm{CD} 1 \mathrm{a}^{+}$cells (Table 5), although low levels of (other) TCRD, TCRG, and/or TCRB recombinations in the $\mathrm{CD} 34^{+} / \mathrm{CD} 1 \mathrm{a}^{-}$subset cannot be fully excluded. The $T C R D$ rearrangement pattern of the transfectants was also compared with TCR recombination data in human T-ALL $\left(\mathrm{CD}^{-}, \mathrm{TCR} \alpha \beta^{+}\right.$, and $\mathrm{TCR} \gamma \delta^{+}$) and precursor B-ALL samples, as investigated in our laboratory (Table 5). ${ }^{6,44-47}$ In T-ALL, J $\delta$ recombinations are predominant, especially in $\mathrm{CD}^{+} \mathrm{T}-\mathrm{ALL}$, whereas $\mathrm{D} \delta 2-\mathrm{D} \delta 3$ and V $\delta 2-\mathrm{D} \delta 3$ rearrangements are found only at low frequencies in immature CD3-T-ALL. ${ }^{6,41,44}$ Interestingly, these latter 2 TCRD rearrangements are very characteristic in precursor B-ALL, where they constitute approximately $80 \%$ of the identified (cross-lineage) TCRD recombinations. ${ }^{6,44}$ Rearrangements involving $\mathrm{J} \delta$ have not been found in precursor B-ALL. ${ }^{6,44,48}$ The data thus suggest that E2A or HEB can induce the very early TCRD recombinations that carry a less T-cell-specific character, as they are also readily observed in precursor B-ALL (Figure 5).

In the transfected cells, $\mathrm{V} \gamma \mathrm{I}-\mathrm{J} \gamma 1.3 / 2.3$ rearrangements were readily observed; such recombinations are also frequent in both T-ALL and precursor B-ALL, albeit in the latter J $\gamma 2.3$ is less frequently involved than $\mathrm{J} \gamma 1.3$; V $\gamma \mathrm{IV}-\mathrm{J} \gamma 1.3 / 2.3$ couplings are less prominent in both ALL subsets. Finally, incomplete D $\beta-\mathrm{J} \beta$ and complete $\mathrm{V} \beta-\mathrm{J} \beta$ recombinations were not detected in the transfectants, but occur in all 3 T-ALL subtypes and at a lower frequency in human precursor B-cell leukemias (approximately $35 \%$ of cases). ${ }^{6}$ Together, these data illustrate that the TCR gene recombination pattern as observed in the E2A or HEB plus RAG-transfected cells concerns the more immature types of TCR recombinations, as observed in $\mathrm{CD} 34^{+} / \mathrm{CD} 1 \mathrm{a}^{-}$thymocytes and also in precursor B-ALL, with the exception of the lack of TCRB rearrangements (Figure 5).

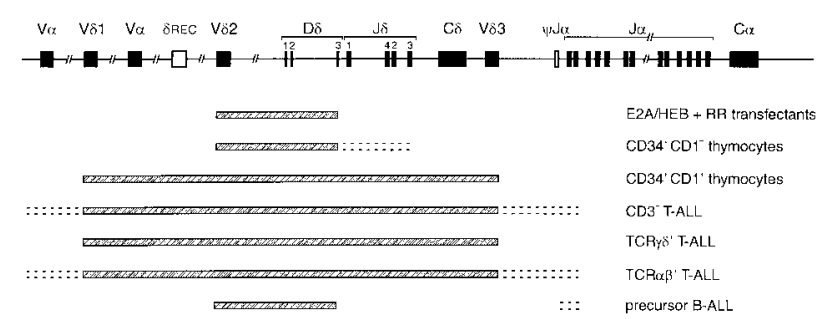

Figure 5. Compilation of TCRD recombination patterns. Indicated are the parts of the TCRD locus that can rearrange in the E2A and HEB transfectants described in this study, CD34 ${ }^{+} / \mathrm{CD}_{1} \mathrm{a}^{-}$and $\mathrm{CD} 34^{+} / \mathrm{CD} 1 \mathrm{a}^{+}$thymocyte subsets, CD3 ${ }^{-}$and TCR $\gamma \delta$ and TCR $\alpha \beta$ T-ALL, and precursor B-ALL. The pattern observed in the E2A/HEB-plusRR-transfected cells is strikingly similar to that of the most immature thymocytes and the cross-lineage pattern of precursor B-ALL, illustrating that E2A and HEB can induce the immature and less T-cell-specific rearrangements in the TCRD locus.
Although recombination can be induced relatively easily in this transfection system, the efficiency seems to be too low to allow detection of recombination events that occur in 2 consecutive steps. This is best illustrated by our study on circular intermediate products that are formed during recombination. Upon study of

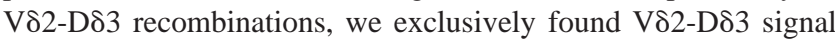
joints and no V $\delta 2-\mathrm{D} \delta 2$ plus $\mathrm{D} \delta 2-\mathrm{D} \delta 3$ circular intermediates. Although we cannot formally exclude that, eg, 2-step V $\delta 1-J \delta 1$ or V $\delta 2-J \delta 1$ rearrangements can be induced at very low levels, the fact that the single-step D $83-\mathrm{J} \delta 1$ and D $\delta 3-\mathrm{J} \delta 3$ recombinations are also undetectable strengthens our view that $\mathrm{J} \delta 1$ rearrangements are truly absent in E2A- or HEB-transfected cells rather than being an artifact in the model system. The same seems to be true for $\mathrm{D} \beta-\mathrm{J} \beta$ and $\mathrm{V} \beta-\mathrm{J} \beta$ rearrangements, as well as $\delta \mathrm{REC}-\psi \mathrm{J} \alpha \mathrm{TCRD}$ deletional rearrangements. The TCRD recombination data thus suggest that E2A and HEB are able to regulate recombination of, especially, the D $\delta 3$ gene segment, but that other factors are required to open up the downstream region of the J $\delta$ segments to the $\mathrm{V}(\mathrm{D}) \mathrm{J}$ recombinase. The area between $\mathrm{D} \delta 3$ and the $\mathrm{J} \delta$ region might harbor important regulatory elements that can bind factors mediating the truly T-cell-specific types of TCRD recombinations. ${ }^{49}$ Interestingly, $\mathrm{V} \delta$-D $\delta$ intermediates are lacking in $\mathrm{E} 2 \mathrm{~A}^{-1-}$ mice, but $\mathrm{D} \delta$-J $\delta$ intermediates do still occur, ${ }^{15}$ which indeed suggests the involvement of one or more yet unknown transcription factors. From $\mathrm{E} 2 \mathrm{~A}^{-1-}$ mice, it is further deduced that E2A plays a role in regulation of $\mathrm{V} \gamma / \mathrm{V} \delta$ subsets during ontogeny by activating and repressing $\mathrm{V}$ segments. ${ }^{15}$ These data fit perfectly with our model system, in which E2A can induce rearrangements of specific $\mathrm{V} \gamma$ gene segments and $\mathrm{V} \delta$-D $\delta$ rearrangements, but not incomplete $\mathrm{D} \delta$-J $\delta$ or complete $\mathrm{V} \delta$-J $\delta$ rearrangements.

From the initial V(D)J recombination study in this nonlymphoid model system, it is known that induction of recombination by, eg, E2A is critically dependent on activation domains. ${ }^{23}$ This has led to the hypothesis that E-box proteins such as E2A are involved in regulating chromatin accessibility by relieving the repressive effect of nucleosomes, most probably through recruitment of complexes containing histone acetyl transferase activity. ${ }^{23,50}$ We therefore hypothesize that the interaction of E2A and HEB with chromatin leads to accessibility of RSS sequences of TCR loci as well, which is supported by the observation of $\mathrm{V} \gamma \mathrm{I}$ and $\mathrm{V} \delta 2$ germline transcripts upon E2A or HEB transfection (J. K. Ghosh et al, personal communication, 2001). The proximity of gene segments, as in the case of $\mathrm{D} \delta 2$ and $\mathrm{D} \delta 3$ and also $\psi \mathrm{V} \gamma 7$ and $\mathrm{V} \gamma 8$ within the $\mathrm{V} \gamma \mathrm{I}$ family, might be another relevant factor. Finally, the exact nucleotide sequence of the RSS might also influence recombination, although the RSSs of, eg, the various V $\gamma \mathrm{I}$ family gene segments are equally perfect in that respect.

The observations in this study raise the issue of how E2A and HEB are involved in regulating TCR recombination during in vivo T-cell differentiation. Both E2A and HEB knock-out mice show a block, though not complete, in the early double-negative stages of T-cell differentiation. The phenotype of these mice thus illustrates the important role of both E2A and HEB in the earliest phases of T-cell differentiation, although the incompleteness of the differentiation arrest indicates some degree of redundancy by other regulatory factors. Using the in vitro model, we show that some types of immature TCR rearrangements can be induced by E2A or HEB, whereas the absence of these rearrangements in E2A knock-out mice shows that E2A and HEB are probably also involved in stimulating the immature TCR recombination in vivo. For induction of further (more mature) rearrangements, additional cofactors or transcription factors might be required or negative 
regulatory elements might have to be downregulated at certain differentiation stages. Moreover, we cannot fully exclude a cooperative action of both E2A and HEB in particular recombinations in vivo, although we have not seen a synergistic effect of combined transfection of E2A and HEB with RAG proteins (data not shown).

Besides mediating physiological immunoglobulin/TCR gene rearrangements, $\mathrm{V}(\mathrm{D}) \mathrm{J}$ recombination is also thought to be involved in the formation of particular chromosome aberrations in human leukemias. ${ }^{25,26}$ This especially concerns chromosome aberrations in T-ALL, in which TCRB or TCRD gene segments and their regulatory elements are translocated to oncogenes on partner chromosomes, resulting in activation of the oncogenes. Examples include translocations $t(1 ; 14)$ and $t(11 ; 14)$, involving the genes encoding the TAL1 and LMO1/LMO2 transcription factors, respectively. ${ }^{25,51}$ As the breakpoint regions on these chromosomes have been found to be located near RSS or RSS-like sequences, ${ }^{25-27}$ it is suggestive that accessibility of the involved oncogenes to RAG protein activity might be a critical step in the formation of these chromosome aberrations as well. We therefore also studied TALI deletions, which are V(D)J-like rearrangements that are found exclusively in T-ALL, particularly in T-ALL with TCRD deletions. ${ }^{52}$ However, such RSSmediated TAL1 deletions were not induced upon E2A or HEB transfection (data not shown). Given the relatively low frequency of $\mathrm{V}(\mathrm{D}) \mathrm{J}$ recombinations in nonlymphoid cells, it can be argued that detection of TAL1 deletions in this model system would be very difficult. However, it might also be that transcription factors other than E2A and HEB regulate accessibility of the TAL1 gene and that an aberrant combination of regulatory factors is required to induce these unwanted oncogenic TAL1 deletions.

In summary, our data demonstrate a role for the bHLH proteins E2A and HEB in induction of TCR rearrangements. Comparison with the TCR-rearrangement patterns found in thymocyte subsets and in $\mathrm{T}$ - and $\mathrm{B}$-lineage leukemias indicates that the identified rearrangements in, especially, the TCRD locus are immature and carry a less T-cell-specific character (Figure 5). A challenge for future studies remains the identification of factors that are involved in induction of more T-cell-specific TCR rearrangements, such as (complete) TCRD recombinations involving J $\delta$ couplings and/or $T C R B$ recombinations. Furthermore, it will be interesting to see whether the here-described model system will be helpful in dissecting the molecular processes regulating RSS-mediated chromosome aberrations in human lymphoid leukemias.

\section{Acknowledgments}

Dr R. Benner for continuous support and Drs F. J. T. Staal and T. Szczepanski for critical reading and valuable comments.

\section{References}

1. Tonegawa S. Somatic generation of antibody diversity. Nature. 1983;302:575-581.

2. Schatz DG, Oettinger MA, Baltimore D. The $\mathrm{V}(\mathrm{D}) \mathrm{J}$ recombination activating gene, RAG-1. Cell. 1989;59:1035-1048.

3. Oettinger MA, Schatz DG, Gorka C, Baltimore D. RAG-1 and RAG-2, adjacent genes that synergistically activate $V(D) J$ recombination. Science. 1990;248:1517-1523.

4. van Gent DC, McBlane JF, Ramsden DA, Sadofsky MJ, Hesse JE, Gellert M. Initiation of V(D)J recombination in a cell-free system. Cell. 1995; 81:925-934

5. Sleckman BP, Gorman JR, Alt FW. Accessibility control of antigen-receptor variable-region gene assembly: role of cis-acting elements. Annu Rev Immunol. 1996;14:459-481.

6. Szczepanski T, Beishuizen A, Pongers-Willemse $\mathrm{MJ}$, et al. Cross-lineage T-cell receptor gene rearrangements occur in more than ninety percent of childhood precursor-B-acute lymphoblastic leukemias: alternative PCR targets for detection of minimal residual disease. Leukemia. 1999;13: 196-205

7. Szczepanski T, Pongers-Willemse MJ, Langerak AW, et al. Ig heavy chain gene rearrangements in T-cell acute lymphoblastic leukemia exhibit predominant DH6-19 and DH7-27 gene usage, can result in complete V-D-J rearrangements, and are rare in T-cell receptor alpha beta lineage. Blood. 1999;93:4079-4085.

8. Yancopoulos GD, Alt FW. Developmentally controlled and tissue-specific expression of unrearranged VH gene segments. Cell. 1985;40:271281.

9. Van Dongen JJM, Wolvers-Tettero ILM. Analysis of immunoglobulin and T-cell receptor genes, II: possibilities and limitations in the diagnosis and management of lymphoproliferative diseases and related disorders. Clin Chim Acta. 1991;198:93174.

10. Ktorza S, Blanc C, Laurent C, et al. Complete TCR-delta rearrangements and partial (D-J) re combination of the TCR-beta locus in CD34+7+ precursors from human cord blood. J Immunol. $1996 ; 156: 4120-4127$
11. Blom B, Verschuren MCM, Heemskerk MHM, et al. TCR gene rearrangements and expression of the pre-T cell receptor complex during human T-cell differentiation. Blood. 1999;93:3033-3043.

12. Alt FW, Yancopoulos GD, Blackwell TK, et al. Ordered rearrangement of immunoglobulin heavy chain variable region segments. EMBO J. 1984;3: 1209-1219.

13. Strominger JL. Developmental biology of $\mathrm{T}$ cell receptors. Science. 1989;244:943-950.

14. Raulet DH, Garman RD, Saito H, Tonegawa S. Developmental regulation of T-cell receptor gene expression. Nature. 1985;314:103-107.

15. Bain G, Romanow WJ, Albers K, Havran WL, Murre $C$. Positive and negative regulation of $\mathrm{V}(\mathrm{D}) \mathrm{J}$ recombination by the E2A proteins. J Exp Med. 1999;189:289-300.

16. Stanhope-Baker P, Hudson KM, Shaffer AL, Constantinescu A, Schlissel MS. Cell type-specific chromatin structure determines the targeting of V(D)J recombinase activity in vitro. Cell. 1996;85: 887-897.

17. Murre C, McCaw PS, Baltimore D. A new DNA binding and dimerization motif in immunoglobulin enhancer binding, daughterless, MyoD, and myc proteins. Cell. 1989;56:777-783.

18. Bain G, Gruenwald S, Murre C. E2A and E2-2 are subunits of B-cell-specific E2-box DNA-binding proteins. Mol Cell Biol. 1993;13:3522-3529.

19. Shen CP, Kadesch T. B-cell-specific DNA binding by an E47 homodimer. Mol Cell Biol. 1995;15: 4518-4524.

20. Bain G, Maandag EC, Izon DJ, et al. E2A proteins are required for proper $\mathrm{B}$ cell development and initiation of immunoglobulin gene rearrangements [comment appears in Cell. 1994;79:751-753]. Cell. 1994;79:885-892

21. Zhuang $Y$, Soriano $P$, Weintraub $H$. The helixloop-helix gene E2A is required for $B$ cell formation. Cell. 1994;79:875-884

22. Schlissel M, Voronova A, Baltimore D. Helix-loophelix transcription factor E47 activates germ-line immunoglobulin heavy-chain gene transcription and rearrangement in a pre-T-cell line. Genes Dev. 1991:5:1367-1376.
23. Romanow WJ, Langerak AW, Goebel $P$, et al. $E 2 A$ and EBF act in synergy with the $V(D) J$ recombinase to generate a diverse immunoglobulin repertoire in nonlymphoid cells. Mol Cell. 2000;5: 343-353.

24. Zhuang $\mathrm{Y}$, Cheng $\mathrm{P}$, Weintraub H. B-lymphocyte development is regulated by the combined dosage of three basic helix-loop-helix genes, E2A, E2-2, and HEB. Mol Cell Biol. 1996;16:28982905.

25. Rabbitts TH. Translocations, master genes, and differences between the origins of acute and chronic leukemias. Cell. 1991;67:641-644.

26. Schatz DG, Oettinger MA, Schlissel MS. V(D)J recombination: molecular biology and regulation. Annu Rev Immunol. 1992;10:359-383.

27. Tycko B, Sklar J. Chromosomal translocations in lymphoid neoplasia: a reappraisal of the recombinase model. Cancer Cells. 1990;2:1-8.

28. Hwang LY, Baer RJ. The role of chromosome translocations in T cell acute leukemia. Curr Opin Immunol. 1995;7:659-664.

29. Pear WS, Nolan GP, Scott ML, Baltimore D. Production of high-titer helper-free retroviruses by transient transfection. Proc Natl Acad Sci U S A 1993;90:8392-8396.

30. Kee BL, Murre C. Induction of early B cell factor (EBF) and multiple $B$ lineage genes by the basic helix-loop-helix transcription factor E12. J Exp Med. 1998;188:699-713.

31. Takebe Y, Seiki M, Fujisawa J, et al. SR alpha promoter: an efficient and versatile mammalian cDNA expression system composed of the simian virus 40 early promoter and the R-U5 segment of human T-cell leukemia virus type 1 long terminal repeat. Mol Cell Biol. 1988;8:466-472.

32. Roman CA, Cherry SR, Baltimore D. Complementation of $V(D) J$ recombination deficiency in RAG-1(-/-) B cells reveals a requirement for novel elements in the $\mathrm{N}$-terminus of RAG-1. Immunity. 1997;7:13-24.

33. Pongers-Willemse MJ, Seriu T, Stolz F, et al. Primers and protocols for standardized detection 
of minimal residual disease in acute lymphoblastic leukemia using immunoglobulin and T cell receptor gene rearrangements and TAL1 deletions as PCR targets: report of the BIOMED-1 CONCERTED ACTION: investigation of minimal residual disease in acute leukemia. Leukemia. 1999;13:110-118.

34. Kneba M, Bolz I, Linke B, Hiddemann W. Analysis of rearranged T-cell receptor beta-chain genes by polymerase chain reaction (PCR) DNA sequencing and automated high resolution PCR fragment analysis. Blood. 1995;86:3930-3937

35. Breit TM, Verschuren MCM, Wolvers-Tettero ILM, Van Gastel-Mol EJ, Hählen K, van Dongen JJM. Human T cell leukemias with continuous V(D)J recombinase activity for TCR-delta gene deletion. J Immunol. 1997;159:4341-4349.

36. Langerak AW, Szczepanski T, van der Burg M, Wolvers-Tettero ILM, van Dongen JJM. Heteroduplex PCR analysis of rearranged T cell receptor genes for clonality assessment in suspect $T$ cell proliferations. Leukemia. 1997;11:2192-2199.

37. Pongers-Willemse MJ, Verhagen OJHM, Tibbe GJM, et al. Real-time quantitative PCR for the detection of minimal residual disease in acute lymphoblastic leukemia using junctional regions specific TaqMan probes. Leukemia. 1998;12: 2006-2014.

38. Bruggemann M, Droese J, Bolz I, et al. Improved assessment of minimal residual disease in B cell malignancies using fluorogenic consensus probes for real-time quantitative PCR. Leukemia. 2000;14:1419-1425.

39. Verhagen OJ, Willemse MJ, Breunis WB, et al. Application of germline IGH probes in real-time quantitative PCR for the detection of minimal re- sidual disease in acute lymphoblastic leukemia. Leukemia. 2000;14:1426-1435.

40. Breit TM, Wolvers-Tettero ILM, Hählen $\mathrm{K}$, van Wering ER, van Dongen JJM. Extensive junctional diversity of $\gamma \delta$ T-cell receptors expressed by T-cell acute lymphoblastic leukemias: implications for the detection of minimal residual disease. Leukemia. 1991;5:1076-1086.

41. Langerak AW, Wolvers-Tettero ILM, van den Beemd MWM, et al. Immunophenotypic and immunogenotypic characteristics of TCR $\gamma \delta^{+} \mathrm{T}$ cell acute lymphoblastic leukemia. Leukemia. 1999; 13:206-214.

42. Van den Beemd R, Boor PPC, van Lochem EG, et al. Flow cytometric analysis of the Vbeta repertoire in healthy controls. Cytometry. 2000;40:336345.

43. Feddersen RM, Martin DJ, Van Ness BG. Novel recombinations of the IG kappa-locus that result in allelic exclusion. J Immunol. 1990;145:745750.

44. Breit TM, Wolvers-Tettero ILM, Beishuizen A, Verhoeven M-AJ, van Wering ER, van Dongen JJM. Southern blot patterns, frequencies and junctional diversity of T-cell receptor- $\delta$ gene rearrangements in acute lymphoblastic leukemia. Blood. 1993;82:3063-3074.

45. Langerak AW, Wolvers-Tettero ILM, van Dongen JJM. Detection of T cell receptor beta (TCRB) gene rearrangement patterns in T cell malignancies by Southern blot analysis. Leukemia. 1999; 13:965-974.

46. Moreau E, Langerak AW, van Gastel-Mol EJ, et al. Easy detection of all T cell receptor gamma (TCRG) gene rearrangements by Southern blot analysis: recommendations for optimal results. Leukemia. 1999;13:1620-1626.

47. Szczepanski T, Langerak AW, Willemse MJ, Wolvers-Tettero ILM, van Wering ER, van Dongen JJM. T cell receptor gamma (TCRG) gene rearrangements in T cell acute lymphoblastic leukemia reflect "end-stage" recombinations: implications for minimal residual disease monitoring. Leukemia. 2000;14:1208-1214.

48. Yokota S, Hansen-Hagge TE, Bartram CR. T-cell receptor delta gene recombination in common acute lymphoblastic leukemia: preferential usage of $\mathrm{V}$ delta 2 and frequent involvement of the $\mathrm{J}$ alpha cluster. Blood. 1991;77:141-148.

49. Krangel MS, Band H, Hata S, McLean J, Brenner MB. Structurally divergent human T cell receptor $\gamma$ proteins encoded by distinct $\mathrm{C} \gamma$ genes. Science. 1987;237:64-67.

50. Massari ME, Grant PA, Pray-Grant MG, Berger SL, Workman JL, Murre C. A conserved motif present in a class of helix-loop-helix proteins activates transcription by direct recruitment of the SAGA complex. Mol Cell. 1999;4:63-73.

51. Rabbitts TH, Lefranc MP, Stinson MA, et al. The chromosomal location of T-cell receptor genes and a T-cell rearranging gene: possible correlation with specific translocations in human T-cell leukemia. EMBO J. 1985;4:1461-1465.

52. Breit TM, Mol EJ, Wolvers-Tettero IL, Ludwig WD, van Wering ER, van Dongen JJ. Site-specific deletions involving the tal-1 and sil genes are restricted to cells of the T cell receptor alpha/beta lineage: T cell receptor delta gene deletion mechanism affects multiple genes. J Exp Med. 1993;177:965-977. 